\title{
Doing it together: How co-production underpins the use of social innovation during service delivery
}

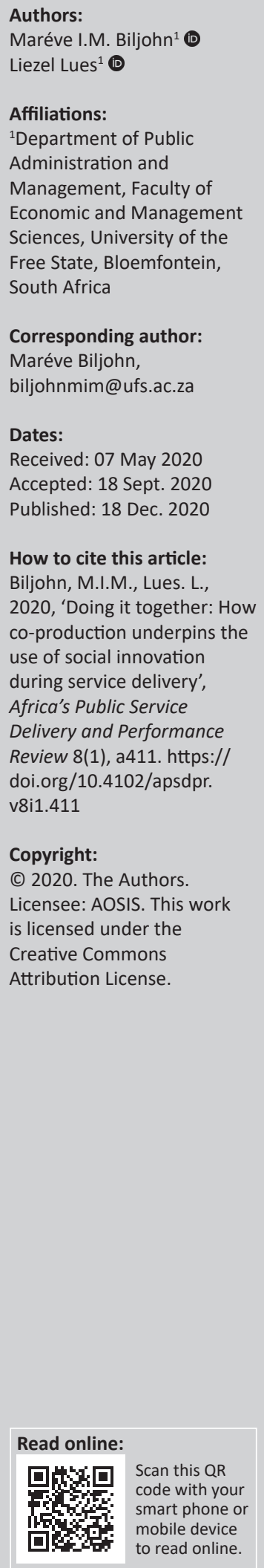

Background: This article focused on the use of social innovation (SI) during local government (LG) service delivery, and how it could enable citizens to participate meaningfully through co-production. The two variables underpinning the conceptualisation of SI in the context of its dual purpose, and that are relevant in this article, are co-production and citizen participation.

Aim: The aim of this article was to investigate how the use of SI could enable citizens to participate meaningfully during the local governance of service delivery through coproduction.

Setting: Through a comparative approach, the research presented in this article investigates the use of SI in LG service delivery in the cases of the City of Ghent (Belgium) and Mangaung Metropolitan Municipality (South Africa).

Methods: The methodology of this study entailed using a qualitative research design that was combined with a case study approach.

Results: It was evident that citizen participation during the co-production of services was influenced by the divergent circumstances and needs of citizens, infrastructure and the availability of resources.

Conclusion: Significantly, this research found that meaningful citizen participation starts with the individual duty of every citizen to protect, preserve and sustainably use the collective goods and services provided by the state.

Keywords: local government; social innovation; co-production; service delivery; citizen participation.

\section{Introduction}

The use of social innovation (SI) as a way of enhancing meaningful citizen participation in local government (LG) service delivery has recently become a survival strategy for LGs, as it offers municipalities new ways of engaging citizens to improve the quality and quantity of public services (Voorberg et al. 2015). When SI is used with a dual purpose that comprises not only finding solutions but also building relationships in order to find such solutions, it replaces the passive role of citizens as service users in the cycle of public service delivery with practices in which co-production is central (OECD 2011; Osborne 2018:228). The two variables underpinning the conceptualisation of SI in the context of its dual purpose, and that are relevant in this article, are co-production and citizen participation. These variables are discussed in this article with the knowledge that there could be other elements that shape the conceptualisation of SI in terms of its dual purpose.

The research presented in this article is part of a doctoral study, which adopted a comparative approach to the use of SI in LG service delivery in the cases of the City of Ghent (COG) (Belgium) and Mangaung Metropolitan Municipality (MMM) (South Africa). Ghent is a city and municipality (LG authority) in the East Flanders province of Belgium, with a population of 252273 citizens who are spread across 25 wards (Stad Gent 2016). The City Council of Ghent, which comprises 51 councillors, serves as the representative body of the citizenry because its members are directly elected by them (Stad Gent 2016).

The MMM is an LG authority in the Free State province of South Africa, with a population of 806942 citizens who are spread across 50 wards (MMM 2016). This municipality's council comprises 97 elected councillors as the public representatives of the citizens (MMM 2016). Of these 
councillors, 48 are representatives of the political parties based on proportional representation and 49 represent the wards in the MMM. A history of city-to-city cooperation between the COG and the MMM since 2004 informed this study (MMM 2016). Even though SI is frequently considered in international studies and frequently used in the COG, this is not necessarily the case in the MMM.

It is noted from the literature that SI has recently been placed high on the agenda and captured in EU policies, regional development funds and programmes (European Commission 2013; Khan et al. 2016; Voorberg et al. 2015). This has culminated in the introduction of projects such as the European SI Governance and Community Building research project (SINGOCOM). By integrating alternative strategies and trajectories to re-socialise and rebuild neighbourhoods and cities in Europe, this project applies SI to satisfy citizens' needs, and thus takes a 'socially innovative view' of development (Moulaert et al. 2007). The European context is different to South Africa; however, the question remains whether SI would have similar successes in the South African LG service delivery context. In South Africa, from 2016 to December 2019, 765 service delivery protests have been recorded in total. This comprises 137 protests in 2016, 173 in 2017, 237 in 2018 and 218 in 2019 (Gous 2019; News24 2020). The biggest reason given for these protests is poor delivery of basic municipal services (Alexandra et al. 2018).

Against this background, this article investigates how the use of SI could enable citizens to participate meaningfully during the local governance of service delivery through coproduction. The two research questions that are answered in this article are: (1) how do citizens participate in the use of SI during LG service delivery? and (2) how does co-production underpin the use of SI during LG service delivery? Through these research questions, this article addresses important debates about the role of citizens who co-produce services with LG and how SI plays a part. The first section of this article conceptualises the interrelatedness of three concepts, namely SI, co-production and citizen participation, all within the LG environment. Findings from the cases of the COG and the MMM are then reported according to the two research questions above.

\section{Conceptualisation in brief}

The origin of SI can be traced back to historical social movements (Banks 1972), local community development initiatives from the 1970s (Moulaert \& Sekia 2003:290), as well as the entrepreneurial philanthropy of Robert Owen (Mulgan et al. 2007) and Andrew Carnegie (Harvey, Maclean \& Gordon 2011:429). Similarly, LG took an interest in SI due to: (1) budget constraints, (2) the need for public-sector activities to be supported through SI (Phillips et al. 2015; Voorberg, Bekkers \& Tummers 2013), (3) the inability of traditional Public Administration and governance theories to address contemporary societal problems and (4) public administrators' lagging success in resolving societal problems (Adams \& Hess 2010). Social innovation, therefore, seems to resonate with policymakers, politicians, as well as citizens (Voorberg et al. 2013:3).

Bourgon (2010) refers to a public-sector reform as transcending the boundaries of the relationship between government and citizens through creative solutions such as SI to achieve better public value in service delivery. Yet, there still appears to be concern regarding the conceptualisation of SI in the service delivery context (also supported by Osborne [2010]). There is a tendency to focus on technological innovation instead of SI, and the meaning of SI remains vague and ambiguous (Grimm et al. 2013). This ambiguity and vagueness stem from the fact that some consider SI a process (embracing networks, collaboration, cooperation and co-production, amongst other things), whereas others only focus on its application in addressing societal problems (Benneworth \& Cunha 2015; Grimm et al. 2013:438; Murray, Caulier-Grice \& Mulgan 2010).

Apart from the ambiguity around the conceptualisation of SI, a lack of clarity concerning its potential benefits for service delivery also seems to influence its use by public sector organisations (Voorberg et al. 2015:14). These potential benefits include improved service delivery and financial gains linked to the use of SI. The real benefit of using SI extends to the creation of public value in the services that are generated through SI processes (Howaldt \& Schwarz 2010). The creation of public value is inherent in the use of coproduction during SI. This emphasises the first variable underpinning the conceptualisation of SI in terms of its dual purpose, namely co-production.

The variable of co-production, which is regarded as a source of public value (OECD 2011), is described as the process of defining the contents of services in collaboration with citizens as service users, as well as the implementation of such services (Bovaird 2007; Marques et al. 2018:15; Needham 2008; Voorberg et al. 2015:14). Unlike traditional Public Administration and governance theories, which often separate the stages of the traditional service delivery cycle, during co-production, these stages are not separated (Vargo, Maglio \& Akaka 2008). Contrary to the traditional service delivery cycle, co-production entails consecutive stages of co-planning, co-design, co-delivery and co-evaluation (OECD 2011). Through these stages, service users, civil society organisations and citizens can participate in the planning, design, delivery and evaluation of public services (OECD 2011). Co-production reduces the limitations that the traditional service delivery cycle presents to citizen participation during public service delivery (Pestoff 2014:1418). In LG, the co-production of services can occur through the participation of individual citizens or community groups (Kinoshita, Dollery \& Yamazaki 2020:173).

The first stage, co-planning, facilitates citizens' participation in service planning through voice, choice and contribution (Biljohn 2018:47). Citizens' role in the co-planning of services relates to expressing their service delivery priorities and preferences, and suggesting solutions to service delivery 
challenges, which can occur through electronic and nonelectronic participatory platforms that are provided (Biljohn 2018:192). For LG officials, their role could include creating platforms (electronic and non-electronic) that facilitate citizen participation in the planning of services (Biljohn 2018:191). During these engagements, consensus should be reached with citizens regarding service delivery priorities as well as solutions to address these priorities (Biljohn 2018:191).

The second stage, co-design, entails citizen participation in the planning and creation of processes and activities that would satisfy the needs and priorities identified during the co-planning stage (Campanale, Mauro \& Sancino 2020:4). The role of citizens in the co-design of services relates to expressing their choice and preference of how they want a service to be delivered to them by detailing, amongst other things, time, location, frequency and mode of delivery, as well as designing the layout of services (Biljohn 2018:193). The role of the LG officials in co-designing services relates to consulting citizens in terms of designing the service they identified during the co-planning stage (Biljohn 2018:192). These services can be co-designed through electronic platforms, non-electronic platforms or a combination of both (Biljohn 2018:192). During the redesigning of the service, the beneficiaries of the particular service should be the main participants and are therefore crucial to this stage (Biljohn 2018:192).

The third stage, co-delivery, encompasses the delivery of services as per the implementation of the designed processes and activities that were identified during co-designing (Campanale et al. 2020:4). Citizen participation in the codelivery of services could be through taking initiative in the submission of plans and proposals to the municipality related to service delivery (Biljohn 2018:194). Citizens can also serve as a delivery mechanism on behalf of the municipality through the establishment of community cooperatives to deliver services (Biljohn 2018:194). Local government officials, on the other hand, could partner with citizens in the co-delivery of services by identifying services that citizens can deliver (Biljohn 2018:193).

The fourth stage of co-evaluation requires citizen participation in the monitoring and evaluation of services delivered (Campanale et al. 2020:4) through suggestions, opinion polls and proposals towards enhancing the quality of service delivery for public value creation (Biljohn 2018:195). During the co-evaluation of services, officials should ensure that services are evaluated and view citizens as partners in this, by making it easy for citizens to participate in the evaluation of services through the available platforms (Biljohn 2018:194). The evaluation of services also includes citizens offering suggestions and alternatives to improving service delivery (Biljohn 2018:195).

Citizens, as service users, are central to the design and delivery of public services in the respective stages, whilst government administrators take the lead with implementation
(Pestoff 2014; Stenvall et al. 2014:23). Citizens' participation in these stages of the co-production service delivery cycle enables them to become more assertive about the services that are delivered to them (Marques et al. 2018:17; Pestoff \& Brandsen 2010). They start to realise the contribution they can make towards their relationship with the government as the producer of services (Osborne 2010). This awareness culminates in an interdependent relationship between government administrators and citizens as service users (Bovaird 2007; Voorberg et al. 2017:365). Underpinned by citizen participation, this interdependence is not only a variable of SI but also seems to be an integral element of coproduction.

When government administrators recognise that they do not have all the knowledge or solutions regarding the circumstances of service users (Stenvall et al. 2014:25), service users' engagement through co-production provides government administrators with added information. Co-production thus results in improved quality and quantity of service delivery (Brudney \& England 1983), which consequently enhance traditional forms of service delivery and lead to higher citizen satisfaction because services are customised to their needs (Djellala, Gallouja \& Milesb 2013; Stumbraitè-Vilkišienė 2011; Vamstad 2012; Verschuere, Brandsen \& Pestoff 2012). The emphasis now shifts to the second variable underpinning the conceptualisation of SI in terms of its dual purpose, namely citizen participation.

Citizen participation is defined as efforts that are organised to achieve increased control over institutions of a regulatory nature - as well as their resources - by those who are excluded from such control (Stumbraitè-Vilkišienè 2011:4). Citizen participation is often mandated by four groups, namely: (1) voters, (2) citizens who contribute to policy processes through representative and stakeholder organisations (Jing \& Gong 2012), (3) end-users who expect affordable services and value for money and (4) organised partners who contribute to the mobilisation of resources for development purposes (Jiménez Escobar \& Morales Guetiérrez 2011:35). Bourgon (2010) proposes that through their contributions, citizens can participate as value creators, as change agents and as users who are required to obtain public results.

Citizens have recently gained increased relevance (Jiménez Escobar \& Morales Guetiérrez 2011) with regard to their role in finding solutions to societal problems and problems in LG service delivery (Adams \& Hess 2010; Jiménez Escobar \& Morales Guetiérrez 2011). Adopting these solutions includes expanding citizens' capacity as new actors and as organised partners. The expansion of their capacity enables citizens to make a notable contribution to the creation of public value, and, through collaborations, such contributions can be made in terms of different levels of input (Adams \& Hess 2010; Voorberg et al. 2017:366). Collaboration is consistent with the use of SI (Cajaiba-Santana 2014), which is underpinned by active citizen collaboration with LG, and it culminates in new compelling relationships that previously separated 
individuals and groups (Neumeier 2012; Piñeiro-Antelo \& Lois-González 2019:12; Voorberg et al. 2017:366; Zhang 2019:38). It is for this specific reason that LG collaborations and partnerships with citizens are significant: they allow LG to develop a relationship with citizens, through which citizens can participate in decision-making regarding services and even service governance (Eurofound 2013).

From this, it is evident that service delivery improvements cannot occur in the absence of such collaborations and partnerships with citizens because, through these partnerships, LG can continue to be responsive to complex societal problems (Bourgon 2010; Voorberg et al. 2013). For LG, the benefits of collaborations and partnerships include LG council decisions that are better informed when linked to citizens' views (Lowndes, Pratchett \& Stoker 2001). For citizens, the benefits of collaborations initiated through SI include, amongst other things, being able to participate in decision-making, which allows them to take part in the creation of public value themselves. For both citizens and LG, the benefits associated with such collaborations and partnerships could be improving service delivery, saving costs (Hilvert \& Swindell 2013) and increasing the probability of service needs being met (Raipa \& Petukienè 2009:55-58). From collaborations between citizens and LG during the use of SI, the empowerment of citizens also emerges as fundamental to the governance of service delivery, a key role of LG (Williamson 2014).

\section{Methodology}

A qualitative research approach that uses qualitative research methods was selected for this study to both collect and

\begin{tabular}{|c|c|c|}
\hline \multicolumn{3}{|c|}{ A qualitative research approach } \\
\hline \multicolumn{3}{|c|}{ A qualitative research design } \\
\hline \multicolumn{3}{|l|}{ Stages } \\
\hline \multicolumn{2}{|c|}{ 1. Conceptual } & 3. Empirical \\
\hline \multicolumn{3}{|c|}{ Research questions } \\
\hline \multicolumn{3}{|c|}{$\begin{array}{l}\text { RQ1. How do citizens participate during the use of SI during LG service delivery? } \\
\text { RQ2. How does co-production underpin the use of SI during LG service delivery? }\end{array}$} \\
\hline \multicolumn{3}{|c|}{ Data collection instruments } \\
\hline \multirow[b]{2}{*}{ Literature } & Relevance & Protocol \\
\hline & $\begin{array}{l}\text { Contributes to enriching and } \\
\text { verifying evidence and } \\
\text { information in case study } \\
\text { research }\end{array}$ & $\begin{array}{l}\text { Use the research question(s) to } \\
\text { demarcate the literature search } \\
\text { Analyse the literature } \\
\text { Summarise the findings }\end{array}$ \\
\hline \multirow{2}{*}{$\begin{array}{l}\text { Focus } \\
\text { group } \\
\text { discussions }\end{array}$} & $\begin{array}{l}\text { Obtain first-hand knowledge and } \\
\text { experience from the sample that } \\
\text { is affected by the phenomenon }\end{array}$ & $\begin{array}{l}\text { Conduct focus group discussions } \\
\text { Audio record the focus group } \\
\text { discussions }\end{array}$ \\
\hline & $\begin{array}{l}\text { Generate data from participants } \\
\text { in relation to their recounting of } \\
\text { the phenomenon that is being } \\
\text { explored }\end{array}$ & $\begin{array}{l}\text { Transcribe the discussions } \\
\text { verbatim }\end{array}$ \\
\hline \multicolumn{3}{|c|}{ Data analysis } \\
\hline
\end{tabular}

SI, social innovation; LG, local government.

FIGURE 1: Stages of the qualitative research design. analyse the data (Figure 1) through a comparative approach. This approach was chosen because the phenomenon was studied through two research questions relating to the nature of the phenomenon. A qualitative research design with a case study approach was used to investigate how the use of SI could enable citizens to participate meaningfully in the governance of LG service delivery, through co-production. This research design consisted of a three-stage process, comprising a conceptual stage, a theoretical stage and an empirical stage (Figure 1). These sampling methods were deemed to be a valid and reliable option as it allowed the researcher to: (1) include research participants who meet the criteria for inclusion in the study, and (2) select predefined groups to participate in this study based on their ability to provide rich information relating to the research questions. The sampling methods were also deemed the best methods available because the research population was inaccessible to the researcher.

The conceptual stage involved conducting a literature review and mapping selected data sources according to the aim of the study (Figure 1). This literature review presented a comprehensive and objective summary of the best evidence regarding the topic. During the theoretical stage, perspectives on local governance and the use of SI in LG service delivery were investigated. The empirical stage comprised focus group discussions with citizens from the COG and the MMM, respectively (Figure 1). A pilot study, using draft questions, was done with four participants with similar characteristics to the participants envisaged for the study. Based on feedback and observations from this pilot study, adjustments were made to the final questions if they appeared to be misleading.

The data collection instruments included documents (naturally occurring data) as well as focus group discussions (generated data). The data collected from the documents informed the focus group discussions. Figure 1 summarises the respective data collection instruments and their relevance, along with the associated protocol that was followed for each data collection technique. Focus group discussions offered research participants the opportunity to share insightful meaning, explanations, experiences, as well as personal views. The data collection protocol that was used for the focus group discussions involved conducting the focus group discussion, making an audio recording of the discussion whilst conducting it, and, upon concluding the discussion, transcribing it verbatim. Data analysis involved transcribing the data from the audio recordings as well as the notes that were taken by the moderator and assistant moderator during the semi-structured interviews and the focus group discussions. In each case, the data were sorted and synthesised according to the research questions. Synthesising or summarising the data entailed analysing the relevance and meaning of the data to the phenomenon under inquiry.

The population was selected based on the geographical location and the focus of the study, as well as the participants' ability to provide relevant and rich information relating to 
the research questions. Consequently, two non-probability sampling methods, namely purposive sampling and snowball sampling, were used to select the projected sample (n), which amounted to 42 participants. Of the projected 21 COG citizens (from the wards Stationsbuurt Noord and Gentbrugge), 20 participated in the focus group discussions, and of the projected 21 MMM citizens (from wards 20 and 23), 20 participated in the focus group discussions. The purposive sampling was also 'adjusted to accommodate snowball sampling', a method that is often applied when the population is 'difficult to find or where the research interest is in an interconnected group of people', as in the case of the citizens (Maree et al. 2020).

\section{Discussion}

Findings from the case of the COG and the MMM are reported according to the two research questions, namely: (1) How do citizens participate in the use of SI during LG service delivery? and (2) How does co-production underpin the use of SI during LG service delivery?

\section{How do citizens participate in the use of social innovation during local government service delivery?}

To address the first research question, the responses to the three questions posed are discussed below. Citizens were asked about their understanding of the concept of SI when it comes to LG service delivery. The majority of the COG respondents were not familiar with the concept of SI but still indicated that they understood that using SI during service delivery is important. It was interesting that although the respondents indicated that they were not knowledgeable about the concept of SI, they still gave several examples of times when they participated in SI during service delivery. Respondents from the MMM indicated that innovation means change and the change that citizens see in service delivery'. Social innovation was described as the public's or the municipality's involvement with citizens, or as doing things differently, which means 'to think out of the box, to have citizens delivering and receiving services'. Respondents indicated that they have not participated in SI during service delivery by the MMM. This was attributed to a lack of leadership by the municipal council, a lack of communication between citizens and the municipality, and their lack of willingness to participate in service delivery initiatives. It was noted that citizens were willing to participate in SI to provide assistance in respect of service delivery and to start service delivery initiatives. However, respondents were not sure whether they were expected to come forward with SI initiatives, and they questioned the willingness of the MMM to support their initiatives.

Citizens were probed regarding their understanding of the concept of 'citizen participation in service delivery' by the COG. Respondents felt that they had a contribution to make in terms of decision-making concerning service delivery that affects them. Examples mentioned were the initiatives called Buren sorg and Buurt werken. The Buren sorg initiative involves citizens' participation in service delivery in terms of assisting and taking care of their neighbours. The Buurt werken initiative focuses on taking care of neighbourhoods and looks at ways to improve those neighbourhoods. It was noted that the COG supports both initiatives, but expects citizens to implement them. Not only do citizens participate physically and mentally but often use their own resources as well. Citizens pointed out that their participation in the delivery of services should include being involved in decision-making processes.

Regarding their understanding of the concept of 'citizen participation in service delivery', respondents from the MMM associated their participation in service delivery with the protection and preservation of the country and stated that this is a responsibility that rests with all citizens. Thus, it was recommended that there should be a sense of responsibility amongst citizens to address one another concerning service delivery. This responsibility includes keeping neighbourhoods clean and informing businesses in the neighbourhood about their responsibility to keep the areas in front of their premises clean. Respondents were, however, of the view that some South African citizens fear to take on this responsibility and 'fear participation in service delivery', which is linked to the 'race card' that is often played when South African citizens reprimand fellow citizens in respect of service delivery.

Respondents also associated citizen participation in service delivery with the establishment of forums in which they can participate such as ward committee meetings and open council meetings. It was recommended that the MMM should consult regularly with citizens through the established forums or meetings, and should be open with citizens concerning new developments affecting them in their neighbourhoods. It was noted that their participation can be facilitated through more open council and ward committee meetings, during which citizens can bring up specific service delivery problems. Unfortunately, it was noted that ward committee meetings have not been held over the past 2 years, and, in some cases, respondents were not even aware of who their ward councillor is. Although citizen participation is also seen as being involved in budgetary processes concerning service delivery for the ward and in making proposals concerning service delivery, respondents were not sure to whom proposals should be submitted, and they mentioned that the municipality should be more sympathetic to citizens' needs. Paying for municipal services used is highlighted as integral to citizen participation in service delivery, but a culture of non-payment for basic municipal services is prevalent.

Citizens were asked whether their LG allows citizen participation in its decision-making processes when it comes to service delivery, and they were required to motivate their answers to this question. In the case of the COG, the majority appeared to agree that a platform has been created to allow 
citizen participation, although some responses were inconclusive. For example, the six Local Service Committees (LSCs) represent citizens from the respective wards in the COG. Approximately every 2 years, the COG council has a public meeting with the members of the LSCs as well as ordinary citizens to discuss current and new challenges as well as issues relating to senior citizens. However, some focus group respondents, as well as the LSC representatives, believed that they are not adequately consulted about the service delivery decisions taken by the COG council. An example provided was that when the COG built the Knoop (a local service centre aimed at ensuring that local residents, especially the elderly, have a good quality of life at home for as long as possible), it did not consider the accessibility of this building for senior citizens or those who are physically challenged and use wheelchairs. It was emphasised that this situation could have been avoided if the COG had consulted with citizens for advice before making decisions and not during or after the decision-making processes.

Respondents from the MMM noted that they do not participate in service delivery decision-making processes, although some remarked that with the new ward councillor, they 'can see something happening' because they receive regular 'SMSes' from the ward councillor. This councillor has also requested citizens to assist with certain services. Some respondents indicated that they received information concerning service delivery decision-making processes through the media, such as the radio and newspapers. Even so, it was remarked that MMM officials neither react to nor make contact with citizens, although the respondents would like to have such direct contact and emphasised the importance thereof. Respondents indicated that they are thus not always aware of how they could be involved in decisionmaking processes when it comes to service delivery. It was suggested that the City Planning Department should make a comprehensive presentation to citizens about its current projects as well as on how to establish a more effective way of involving citizens in decision-making processes.

Respondents were asked to support their responses with examples of how they have participated in the decisionmaking processes of LG when it comes to service delivery. Whilst citizens from the MMM could not recall examples of how they have participated in such processes, the citizens from the COG had several examples to share. The first example related to when the COG invites participation to evaluate its policy plan, normally mid-way through the 6-year term of the legislature. Citizens, amongst whom are the LSC representatives, are invited to evaluate the progress made in relation to the objectives that were set within the framework of the policy plan, thus allowing citizens and LSC representatives to give input in respect of existing and future plans. The 'ward of the month' initiative was provided as a second example of how citizens participated in service delivery decision-making in their respective wards. The COG sets up a platform for citizens to articulate their service needs and their preferences for service delivery and to participate in decision-making processes concerning the affordability and accessibility of services at local service centres. It was noted, however, that the COG still takes 'most decisions' concerning services.

A third example mentioned was the co-housing project, which falls under the current social housing initiative of the COG. This project aims to encourage the concept of mixed housing, where younger and elderly people share an apartment. The concept of mutual benefit is the main driver for this initiative. Within an apartment, a room would be rented to a younger person who would then assist the elderly person in daily tasks. Prior to building the cohousing apartments, the COG asked citizens from the ward for their opinion about such a co-housing project, what they considered important in such a project and what they wanted in their specific apartment in such a co-housing project. A similar example to the co-housing initiative, the inspraak wandelingen, was mentioned as an example of participation in the decision-making process of the COG. About 10 years ago, when a nature reserve in a certain neighbourhood was renovated, the citizens and schoolchildren from that neighbourhood, together with the COG officials, walked through the nature reserve to determine what they envisaged for the renovated nature reserve. It was mentioned that the suggestions made were only materialising in 2016 (10 years later).

\section{How does co-production underpin the use of social innovation during local government service delivery?}

It was deemed important to establish in which of the stages of the co-production of services (co-planning, co-design, codelivery and co-evaluation) citizens have participated, and for them to give an example of how they participated in the co-production of services by LG. Further, it was important to know what the nature of this participation was and whether their participation in the co-production of this service was to find or plan, design or deliver an innovative solution to service delivery. From the responses, it appeared that some citizens from the COG have participated in the co-planning of services. Responses concerning the co-planning of services included an example of some citizens who were invited by the COG to participate in compiling the city's plans for the Multi-Annual Plan to inform the City Council of their service needs. It was noted that this invitation, however, was only extended to representative organisations and not to ordinary citizens. A second example was when the citizens from a particular neighbourhood asked the COG for permission to use a particular unutilised building in their neighbourhood, namely the Standaard site in Lederberg. The COG bought the property, and these citizens participated in planning how this space should be utilised. A third example was when citizens participated in planning the neighbourhood around a new football stadium. This participation encompassed their input in the type of housing and apartment buildings for this area, mobility within this area, the layout of streets and parks, and the ecological impact on this area. 
A fourth example was a system called 'public investigations', during which the COG consults citizens when it undertakes big building plans. Citizens are invited to a public meeting to voice their opinions concerning the building plans, and the COG then incorporates citizens' input in the building plans. It was also reported that some citizens, particularly senior citizens, do not participate in these co-planning initiatives because of the time of the meeting, as they are scared to go out at night. The view was that these types of co-planning initiatives are of more interest to younger citizens, and those senior citizens especially are not listened to during co-planning and consultative meetings, such as ward of the month.

At a ward-based level, this participation of citizens in the codesign of services includes being consulted prior to some services being delivered. This includes indirect as well as direct citizen participation in the redesigning and renewing of some services. This participation of citizens in the codesign of services is not necessarily after citizen participation in the co-planning of a new service but also occurs in conjunction with the co-planning of new activities and services at ward level. Although the citizens in the focus group have not participated in the delivery of services, they explained that the co-delivery of services does take place in other wards of Ghent, for example Lederberg and Rabot. It was explained that the citizens who participate in the delivery of these services in the aforementioned wards do not receive remuneration but are instead rewarded in the form of a voucher that they can use, for example to buy bread or that they can trade for a product or service. In Lederberg, this voucher is called the Pluimen, and in Rabot, the Torkes is used to remunerate citizens who participate in the co-delivery of services by the COG.

It was noted that some citizens have participated in the 3-year evaluation of the COG Multi-Annual Plan. Respondents explained that they were divided into small discussion groups during which different subjects were discussed, including 'mobility in the city', healthcare issues such as how the COG can become a 'dementia-friendly city', what can be done to 'integrate people from different nationalities in neighbourhoods', as well as 'what the service needs of citizens are'. Responses included that some citizens have been involved in evaluating the services delivered by the COG, for example electronically via its 'website and in writing on paper'. It was pointed out that the evaluation of services via the Internet inhibits their participation and that of other citizens who do not have access to the Internet. Though the majority of citizens indicated that they were not involved in the co-evaluation of services, some citizens indicated they are willing to evaluate services if requested to do so by the COG. Respondents shared that when they receive evaluation forms from the COG, they simply do not complete them because they have lost confidence in the system, and they felt that there is no improvement in some services, even when they provide their opinion about the quality of the service.
In the case of the MMM, citizens could not provide examples of their own participation in any of the four stages of the co-production of services. The lack of participation in the co-planning of services was attributed to the lack of communication between the municipality and citizens. Although respondents learn of scheduled Development Planning meetings through newspaper adverts, perceptions exist that the municipality has already taken service delivery decisions before these meetings. Concerning participation in the co-design of services, respondents noted that they were not aware whether citizens from other wards participated in this. However, although not in their neighbourhoods, participants were aware of citizens co-delivering the maintenance of a park in two neighbourhoods, one of which is Langenhovenpark. In the case of Langenhovenpark, the citizens initiated the co-delivery of the maintenance of a park, and the MMM provides assistance. Thus, it appears that if citizens are prepared to participate in the co-production stages, then it is expected that the municipality should also be prepared to make a contribution. Respondents noted that they have not participated in the co-evaluation of services with the MMM, and were also not aware of citizen participation in such co-evaluation in other wards. It was remarked that when services are co-evaluated, the municipality should at least process these evaluations and make a concerted effort to consider feasible suggestions.

In conclusion, the responses confirmed that the concept of SI is concerned with social inclusion (Kirwan et al. 2013) because social inclusion culminates in new ways of engaging citizens, contributes to the empowerment of marginalised groups and improves the ways citizens participate, all of which could result in meeting citizens' unsatisfied needs (Neumeier 2012, as cited in Kirwan et al. 2013:831). With reference to LG service delivery, Stumbraitè-Vilkišienè (2011:4) argues that inclusion in citizen participation is not only about citizens making contributions, but their participation should also have a real impact on quality service assessments; LG should provide better services and citizens should be satisfied with those services. Social innovation is considered an important process for including citizens by transforming government-citizen relations that resulted from social exclusion (Kim et al. 2015:173). Local governments should, therefore, ensure that they manage the processes of citizen participation and representation with the necessary caution so as not to exclude any particular group of citizens.

At the same time, LGs are obliged to implement strategies that encourage equal participation by all citizens, because citizen participation builds the capacity of the community as a whole as well as of individual citizens (Adams \& Hess 2010:145). Such participatory strategies should include concerted efforts whereby LGs invite citizens to participate in decision-making regarding the provision and governance of services (Stumbraitè-Vilkišienè 2011:6). According to Lowndes et al. (2001) and Stumbraitè-Vilkišienė (2011:6-7), participatory strategies could include: (1) the consumerist methods whereby 
citizens evaluate aspects of LG service delivery and (2) traditional methods of public participation encompassing public hearings, question-and-answer sessions, and community representative consultations. Further strategies could include (3) forums aimed at consulting particular LG service users or citizens with a shared interest or background, (4) consultative innovations aimed at consulting citizens on particular issues and (5) deliberative innovations that encourage citizens to deliberate on issues affecting them (Lowndes et al. 2001; Stumbraitè-Vilkišienè 2011). In addition, participatory strategies also involve encouraging willingness amongst all citizens to participate in the SI process.

\section{Conclusion}

Findings from the case of the COG and the MMM were reported according to the two research questions, namely: (1) How do citizens participate in the use of SI during LG service delivery? and (2) How does co-production underpin the use of SI during LG service delivery?

As regards the first research question, it appears that citizens in the COG defined their participation in service delivery in respect of contributing to decision-making about service delivery that affects them. The initiation of service delivery initiatives and providing assistance with service delivery initiatives were also proposed by citizens as ways they could participate in service delivery. Concerning research question 1, citizens in the MMM associated their participation in SI with seeing a change in service delivery, involvement and interaction between citizens and the MMM, the identification of solutions and giving of advice with the potential for addressing problems in the community, as well as synergies and interactions between politicians, citizens and the LG administration. In both municipalities, willingness amongst citizens was regarded as fundamental to their participation. Whilst some citizens might not have been familiar with the concept of SI, it appeared that they have in fact participated in SI initiatives initiated by the municipality, by themselves or by other stakeholders.

About the second research question, in both municipalities, it is evident that citizen participation during the co-production of services is influenced by the divergent circumstances and needs of citizens, citizens' development level per ward, infrastructure development, as well as the availability of resources. A lack of communication between LG and citizens lost confidence in LG systems, and a lack of improvement in some services seem to deter citizen participation in the coproduction of services. Despite some citizens' willingness to participate in the co-production of services, the use of technology has the potential to inhibit the participation of some citizens who do not have access to the Internet. A significant conclusion that can be drawn from the findings of this research is that meaningful citizen participation is not only confined to formal participation processes created by LG through the use of SI and co-production. In fact, citizen participation starts with the individual duty of every citizen to protect, preserve and sustainably use the collective goods and services provided by the state.

\section{Acknowledgements}

M.I.M.B. would like to express their deepest gratitude for the support received from the Department of Public Administration and Management (University of the Free State) to complete this thesis. Finally, a heartfelt appreciation goes out to the officials and citizens respectively of the City of Ghent (Ghent, Belgium) and Mangaung Metropolitan Municipality (Free State province, South Africa) whose participation made it possible to complete this research.

\section{Competing interests}

The authors have declared that no competing interests exist.

\section{Authors' contributions}

Both authors contributed equally to this work.

\section{Ethical consideration}

This article followed all ethical standards for carrying out research.

\section{Funding information}

This research received no specific grant from any funding agency in the public, commercial or not-for-profit sectors.

\section{Data availability statement}

Data sharing is not applicable to this article as no new data were created or analysed in this study.

\section{Disclaimer}

The views and opinions expressed in this article are those of the authors and do not necessarily reflect the official policy or position of any affiliated agency of the authors.

\section{References}

Adams, D. \& Hess, M., 2010, 'SI and why it has policy significance', The Economic and Labour Relations Review 21(2), 139-156. https://doi.org/10.1177/10353046 1002100209

Alexandra, P., Runciman, C. Ngwane, T., Moloto, B., Mokgele, K. \& Van Staden, N. 2018, 'Frequency and turmoil: South Africa's community protests 2005-2017' South African Crime Quartely 63, 27-42. https://doi.org/10.17159/2413-3108/ 2018/v0n63a3057

Banks, J., 1972, The sociology of social movements, MacMillan, London.

Benneworth, P. \& Cunha, J., 2015, 'Universities' contributions to social innovation Reflections in theory \& practice', European Journal of Innovation Management 18(4), 508-527. https://doi.org/10.1108/EJIM-10-2013-0099

Biljohn, M.I.M., 2018, 'Social innovation and service delivery by local government: A comparative perspective', PhD thesis, University of the Free State, Department of Public Administration and Management Administration and Management, viewed 18 July 2018, from https://scholar.ufs.ac.za/handle/11660/8544.

Bourgon, J., 2010, 'The history and future of nation-building? Building capacity for public results', International Review of Administrative Sciences 76(2), 197-218. https://doi.org/10.1177/0020852309365666

Bovaird, T., 2007, 'Beyond engagement and participation: User and community co-production of public services', Public Administration Review 67(5), 846-860. https://doi.org/10.1111/j.1540-6210.2007.00773.x 
Brudney, J. \& England, R., 1983, 'Toward a definition of the co-production concept', Public Administration Review 43(1), 59-65. https://doi.org/10.2307/975300

Cajaiba-Santana, G., 2014, 'Social innovation: Moving the field forward, A conceptual framework', Technological Forecasting and Social Change 82, 42-51. https://doi. org/10.1016/j.techfore.2013.05.008

Campanale, C., Mauro, S.G. \& Sancino, A., 2020, 'Managing co-production and enhancing good governance principles: Insights from two case studies', Journal of Management and Governance 2020, 1-32. https://doi.org/10.1007/s10997-02009508-y

Djellala, F., Gallouja, F. \& Milesb, I., 2013, 'Two decades of research on innovation in services: Which place for public services?', Structural Change and Economic Dynamics 27, 98-117. https://doi.org/10.1016/j.strueco.2013.06.005

European Commission, 2013, SI research in the European Union Approaches, finding and future directions Policy Review, Publications Office of the European Union, Luxembourg.

European Foundation for the Improvement of Living and Working Conditions (Eurofound), 2013, SI in service delivery: New partners and approaches, Eurofound, Dublin.

Gous, N., 2019, 'Service delivery protests are on the rise this year, warn experts', Sunday Times, viewed 17 June 2019, from https://www.timeslive.co.za/news/ south-africa/2019-06-11-service-delivery-protests-are-on-the-rise-this-yearwarn-experts/.

Grimm, R., Fox, C., Baines, S. \& Albertson, K., 2013, 'SI, an answer to contemporary societal challenges? Locating the concept in theory and practice', The European Journal of Social Science Research 26(4), 436-455. https://doi.org/10.1080/1351 1610.2013.848163

Harvey, C., Maclean, M. \& Gordon, J., 2011, 'Andrew Carnegie and the foundations of contemporary entrepreneurial philanthropy', Business History 53(3), 425-450. https://doi.org/10.1080/00076791.2011.565516

Hilvert, C. \& Swindell, D., 2013, 'Collaborative service delivery: What every local government manager should know', State and Local Government Review 45(4), 240-254. https://doi.org/10.1177/0160323X13513908

Howaldt, J. \& Schwarz, M., 2010, Sl: Concepts, research fields and international trends, International monitoring: Working - Learning - Developing skills, Internationa Monitoring (IMO), Sozialforschungsstelle Dortmund.

Jiménez Escobar, J. \& Morales Gutiérrez, A.C., 2011, 'Social economy and the fourth sector, base and protagonist of SI', CIRIEC-España, Revista de Economía Pública, sector, base and protagonist of
Social y Cooperativa $73,33-60$.

Jing, Y. \& Gong, T., 2012, 'Managed SI: The case of government-sponsored venture philanthropy in Shanghai', The Australian Journal of Public Administration 71(2) 233-245. https://doi.org/10.1111/j.1467-8500.2012.00767.x

Khan, S.S., Timotijevic, L., Newton, R., Coutinho, D., Llerena, J.L., Ortega, S. et al., 2016, 'The framing of innovation among European research funding actors: Assessing the potential for responsible research and innovation in the food and health domain', Food Policy 62, 78-87. https://doi.org/10.1016/j.foodpol.2016. 04.004

Kim, K., Rim, S., Han, S. \& Park, A., 2015, 'Seoul city's social innovation strategy: New models of communication to strengthen citizen engagement', in A. Nicholls, J. Simon \& M. Gabriel (eds.), New frontiers in social innovation research, pp. 170-91, Palgrave Macmillan, New York, NY.

Kinoshita, Y., Dollery, B. \& Yamazaki, K., 2020, 'Creating institutional advantage: Local government co-production with community groups', Asia Pacific Journal of Public Administration 42(3), 170-187. https://doi.org/10.1080/23276665.2020. 1776624

Kirwan, J., Ilbery, B., Maye, D. \& Carey, J., 2013, 'Grassroots SI and food localisation: An investigation of the local food programme in England', Global Environmental Change 23(5), 830-837. https://doi.org/10.1016/j.gloenvcha.2012.12.004

Lowndes, V., Pratchett, L. \& Stoke, G., 2001, 'Trends in public participation: Part 1 Local government perspectives', Public Administration 79(1), 205-222. https:// doi.org/10.1111/1467-9299.00253

Mangaung Metropolitan Municipality (MMM), 2016, End-of-term report 2011-2016, Mangaung Metropolitan Municipality, Bloemfontein

Maree, K., Creswell, J.W., Ebersöhn, L., Eloff, I., Ferreira, R., Ivankova, N.V. et al., 2020, First steps in research, Van Schaik, Pretoria.

Marques, P., Morgan, K. \& Richardson, R., 2018, 'SI in question: The theoretical and practical implications of a contested concept', Environment and Planning $C$ : Politics and Space 36(3), 496-512. https://doi.org/10.1177/2399654417717986

Moulaert, F., Martinelli, F., González, S. \& Swyngedouw, E., 2007, 'Introduction: SI and governance in European cities: Urban development between path dependency and radical innovation', European Urban and Regional Studies 14(3), 195-209. https://doi.org/10.1177/0969776407077737

Moulaert, F. \& Sekia, F., 2003, 'Territorial innovation models: A critical survey', Regional Studies 37(3), 289-302. https://doi.org/10.1080/0034340032000065442
Mulgan, G., Tucker, S., Ali, R. \& Sanders, B., 2007, SI: What it is, why it matters, how it can be accelerated, Skoll Centre for Social Entrepreneurship, Oxford.

Murray, R., Caulier-Grice, J. \& Mulgan, G., 2010, The open book of SI, NESTA, London.

Needham, C., 2008, 'Realising the potential of co-production: Negotiating improvements in public services', Journal of Social Policy and Society 7(2), 221-231. https://doi. org/10.1017/S1474746407004174

Neumeier, S., 2012, 'Why do social innovations in rural development matter and should they be considered more seriously in rural development research? Proposal for a stronger focus on social innovations in rural development research', Sociologia Ruralis 52(1), 48-69. https://doi.org/10.1111/j.1467-9523. 2011.00553.x

News24, 2020, Fewer service delivery protests in 2019 than previous year, says data collecting organization, viewed 04 May 2020, from https://www.news24.com/ SouthAfrica/News/fewer-service-delivery-protests-in-2019-than-previous-yearsays-data-collecting-organisation-20200201.

Organisation for Economic Cooperation and Development, 2011, Together for better public services: Partnering with citizens and civil society, OECD Public Governance Reviews, Organisation for Economic Cooperation and Development Publishing, Paris.

Osborne, S.P., 2010, 'The (new) public governance: A suitable case for treatment?', in S.P. Osborne (ed.), The new public governance: Emerging perspectives on the theory and practice of public governance, pp. 1-16, Routledge, New York, NY

Osborne, S.P., 2018, 'From public service-dominant logic to public service logic: Are public service organizations capable of co-production and value co-creation?', public service organizations capable of co-pro
Public Management Review 20(2), 225-231.

Pestoff, V., 2014, 'Hybridity, coproduction, and third sector social services in Europe', American Behavioral Scientist 58(11), 1412-1424. https://doi.org/10.1177/ 0002764214534670

Pestoff, V. \& Brandsen, T., 2010, 'Public governance and the third sector: Opportunities for co-production and innovation?', in S.P. Osborne (ed.), The new public governance? pp. 223-236, Routledge, London.

Phillips, W., Lee, H., Ghobadian, A., O'Regan, N. \& James, P., 2015, 'SI and social entrepreneurship: A systematic review', Group and Organization Management 40(3), 428-461. https://doi.org/10.1177/1059601114560063

Piñeiro-Antelo, M. \& Lois-González, R.C., 2019, 'The role of European fisheries funds for innovation and regional development in Galicia (Spain)', European Planning Studies 27(12), 1-17. https://doi.org/10.1080/09654313.2019.1635996

Raipa, A. \& Petukienè, E., 2009, 'Klientu dalyvavimas viešosiose paslaugose: Bendrasis paslaugų kūrimas', Viešoji Politika ir Administravimas 27, 54-62.

Stad Gent, 2016, Executive committee, viewed 25 May 2018, from www.stad.gent/ ghent-international/city-policy-and-structure/executive-committee.

Stenvall, J., Laitinen, I., Ursin, K., Virtanen, P. \& Kaivo-Oja, J., 2014, 'Constructing public services: European approach', European Integration Studies 8(1), 22-27. https:// doi.org/10.5755/j01.eis.0.8.6954

Stumbraitè-Vilkišienè, E., 2011, Citizen participation in the local public service provision and quality improvement, Paper delivered at improving the quality of Public Services: A Multinational Conference on Public Management, Moscow, 28-29 June 2011.

Vamstad, J., 2012, 'Co-production and service quality: The case of cooperative childcare in Sweden', Voluntas 23(4), 1173-1188.

Vargo, S., Maglio, P. \& Akaka, M., 2008, 'On value and value creation: A service systems and service logic perspective', European Management Journal 26(3), 145-152. https://doi.org/10.1016/j.emj.2008.04.003

Verschuere, B., Brandsen, T. \& Pestoff, V., 2012, 'Co-production: The state of the art in research and the future agenda', Voluntas 23(4), 1083-1101. https://doi. org/10.1007/s11266-012-9307-8

Voorberg, W., Bekkers, V. \& Tummers, L., 2013, 'Co-creation and co-production in SI: A systematic review and future research agenda', Paper delivered at the EGPA conference, Edinburgh, 11-13 September

Voorberg, W., Bekkers, V., Flemig, S., Timeus, K., Tõnurist, P. \& Tummers, L., 2017 'Does co-creation impact public service delivery? The importance of state and governance traditions', Public Money and Management 37(5), 365-372. https:// doi.org/10.1080/09540962.2017.1328798

Voorberg, W., Tummers, L., Bekkers, V., Torfing, J., Tõnurist, P., Kattel, R. et al., 2015 Co-creation and citizen involvement in social innovation: A comparative case study across 7 EU-countries, Erasmus University Rotterdam, Rotterdam.

Williamson, B., 2014, 'Knowing public services: Cross-sector intermediaries and algorithmic governance in public sector reform', Public Policy and Administration algorithmic governance in public sector reform', Public Policy
29(4), 292-312. https://doi.org/10.1177/0952076714529139

Zhang, S., 2019, 'Public participation in the geoweb era: Defining a typology for geoparticipation in local governments', Cities 85 , 38-50. https://doi.org/10.1016/j. cities.2018.12.004 